\title{
Primary production of benthic microalgae in two shallow coastal lagoons of different trophic status in the southern Baltic Sea
}

\author{
Jürgen Meyercordt”, Lutz-Arend Meyer-Reil \\ Institut für Ökologie, Ernst-Moritz-Arndt-Universität Greifswald, D-18565 Kloster/Hiddensee, Germany
}

\begin{abstract}
Primary production of undisturbed sedirnents, taken from 2 shallow coastal lagoons in the southern Baltic Sea, was measured in situ and in the laboratory. In the highly eutrophicated and turbid water (mean attenuation coefficient $=2.97 \mathrm{~m}^{-1}$ ) of Kirr-Bucht (Darss-Zingster Bodden), chlorophyll $a$ concentrations were about 8 times higher than at moderately eutrophicated (mean attenuation coefficient $=0.66 \mathrm{~m}^{-1}$ ) Rassower Strom (Nordrügensche Bodden). The difference between the 2 areas in terms of chlorophyll a concentrations of the sediment was smaller (only about 2.5 times higher at KirrBucht). Sediment oxygen consumption rates were similar at both sampling stations, showing a marked seasonal trend. Hourly rates of gross production, measured by in situ incubations, revealed maximal values of 30.0 and $17.6 \mathrm{mg} \mathrm{C} \mathrm{m}^{-2} \mathrm{~h}^{-1}$ for sediments of Kirr-Bucht and Rassower Strom, respectively. Agreement between production rates measured in situ and in laboratory incubations was acceptable $\left(R^{2}=0.833\right)$. Irradiance dependency of gross production could be well described by 2 parameters, $\alpha$ (slope of light-saturation curve at low irradiance) and $P_{\mathrm{m}}$ (photosynthetic capacity), of a photosynthesis model. Calculated annual rates for Kirr-Bucht $\left(0.6 \mathrm{~m}\right.$ water depth) were $60 \mathrm{~g} \mathrm{C} \mathrm{m}^{-2} \mathrm{yr}^{-1}$ for gross production and $5 \mathrm{~g} \mathrm{C} \mathrm{m}^{-2} \mathrm{yr}^{-1}$ for net production. For Rassower Strom (3.4 m water depth), $23 \mathrm{~g} \mathrm{C} \mathrm{m}^{-2} \mathrm{yr}^{-1}$ for gross production and $-31 \mathrm{~g} \mathrm{C} \mathrm{m}^{-2} \mathrm{yr}^{-1}$ for net production were calculated. If production rates were extrapolated to irradiance conditions at comparable water depths at both sampling locations (e.g. $1 \mathrm{~m}$ ), the detrimental effect of the eutrophicated water column of Kirr-Bucht on benthic primary production became evident in the gross production rates (Kirr-Bucht: $25 \mathrm{~g} \mathrm{C} \mathrm{m}^{-2} \mathrm{yr}^{-1}$, Rassower Strom: $51 \mathrm{~g} \mathrm{C} \mathrm{m}^{-2}$ $\mathrm{yr}^{-1}$ ) and was even more significant for the net production rates (Kirr-Bucht: $-30 \mathrm{~g} \mathrm{C} \mathrm{m}^{-2} \mathrm{yr}^{-1}$, Rassower Strom: $-3 \mathrm{~g} \mathrm{C} \mathrm{m}^{-2} \mathrm{yr}^{-1}$ ). At a depth of $1 \mathrm{~m}$, a much higher deficit in the carbon balance for the benthic system of Kirr-Bucht was calculated than for Rassower Strom. Therefore, benthic community respiration at the highly eutrophicated location could not by a large margin be balanced by authochthonous benthic primary production, whereas, at the moderately eutrophicated location, benthic respiration and production were nearly balanced.
\end{abstract}

KEY WORDS: Primary production - Microphytobenthos - Irradiance · Eutrophication · Estuary Baltic Sea

\section{INTRODUCTION}

Although up to $30 \%$ of continental shelf waters may support benthic microalgal photosynthesis (Cahoon et al. 1993), the domain of benthic primary production is clearly located in shallow coastal waters. The most important limiting factor for benthic photosynthesis is

\footnotetext{
-E-mail: meyercor@rz.uni-greifswald.de
}

the availability of irradiance at the sediment surface, which besides water depth depends very much on the optical properties of the water (Kirk 1994). Suspended matter and phytoplankton reduce water transparency. Concentrations of both commonly increase towards the coast, causing a rise in turbidity of the water. Even shallow coastal waters may therefore sustain rather poor benthic primary production, because the higher availability of irradiance with decreasing water depth may be counteracted by higher particle concentrations 
in the water (Colijn 1982, Schreiber \& Pennock 1995, Macintyre et al. 1996, Sloth et al. 1996). The semienclosed Bodden waters of the southern Baltic Sea are shallow inlets (mean water depth 2 to $3 \mathrm{~m}$; Dahlke 1994, Schlungbaum et al. 1994) and are moderately to highly eutrophicated (Köster et al. 1997). Conditions for primary production have essentially changed during the past few decades. In the course of an increasing nutrient input, a change from nutrient limitation to light limitation took place (Schiewer et al. 1994), promoting phytoplanktonic primary production. Under conditions of low nutrient concentrations in the water, benthic photoautotrophs benefit from their vicinity to relatively high nutrient concentrations in the pore water of the sediment and from low attenuation of irradiance in the water, due to a limited phytoplankton development. The situation is the reverse under eutrophic conditions. A sufficient nutrient supply in the water allows high phytoplankton densities, causes a strong attenuation of irradiance within the water and leads to extended light limitation for the benthic photoautotrophs. As a conspicuous consequence, the area covered by macrophytes in the Bodden decreased drastically at the end of the 1970 s and the beginning of the 1980s (Pankow \& Wasmund 1994). The significance of microphytobenthic photosynthesis also diminished, and the function of the microphytobenthos as primary producers (nutrient scavengers, food source) has been replaced by sedimented planktonic algae (U. Schiewer pers. comm.).

In this study primary production rates of photoautotrophic communities in undisturbed sediment cores from 2 locations in Bodden waters with different levels of eutrophication were investigated. The first objective was to show seasonal differences in photosynthetic activity of benthic microalgae, sediment oxygen demand (SOD), and carbon budgets, expressed as net production rates. For this purpose the locations were

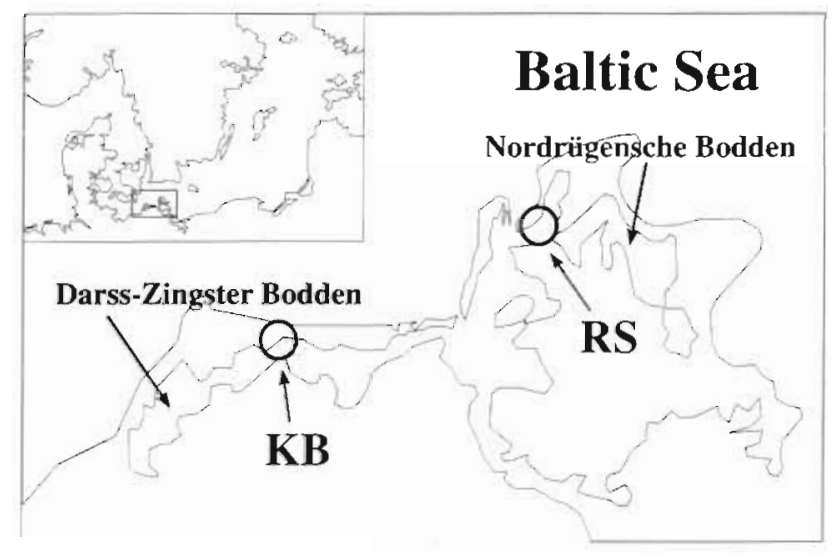

Fig. 1. Locations of the sampling stations Kirr-Bucht (KB) and Rassower Strom (RS) in the southern Baltic Sea sampled in spring, summer, autumn, and winter. The second objective was to test the hypothesis that at a high level of eutrophication the primary production of benthic microalgae is reduced compared to at a lower level of eutrophication. For this purpose the dependency of benthic photosynthesis on irradiance (P-E relationship) was determined during laboratory incubations, and its agreement with rates of photosynthesis in situ tested. The P-E relationship was used to model primary production rates at a moderately and a highly eutrophicated location. The modeling procedure allowed a direct comparison of both locations, because the effect of different water depths at the sampling sites on irradiance levels at the sediment surface could be taken into account.

\section{MATERIALS AND METHODS}

Study sites. The sampling locations Rassower Strom and Kirr-Bucht are part of 2 different systems of shallow estuarine basins located on the southern coast of the Baltic Sea (Fig. 1). Rassower Strom is located in the outer part of the Nordrügensche Bodden, which cover an area of about $154 \mathrm{~km}^{2}$ (Correns 1976). A gradient of practical salinity ranges from about 10 at the outlet to the Baltic Sea to about 5 in the inner parts (Dahlke 1994). In contrast to salinity, a steep reverse gradient in inorganic nutrient concentration exists, causing a high degree of eutrophication in the inner parts of the Bodden (Hübel et al. 1998). Kirr-Bucht is a small shallow basin, located in the central part of the DarssZingst Bodden, which in total cover an area of about $200 \mathrm{~km}^{2}$. The salinity gradient ranges from 9 to $10 \mathrm{at}$ the outlet to the Baltic Sea to $<5$ in the inner part, with a significant input of fresh water (Schlungbaum et al. 1994). Like the Nordrügensche Bodden, the DarssZingst Bodden show a gradual increase in eutrophication towarts the inner parts (Nausch \& Schlungbaum 1991). Hydrographical and hydrochemical data, as well as sediment characteristics of Kirr-Bucht and Rassower Strom, are presented in Table 1. Sampling was carried out in 1996 and 1997 (see Table 2). Due to ice cover, the sampling location Rassower Strom was not accessible in January 1997. For this reason the Iocation Klosterloch, a water basin in the vicinity of Rassower Strom, was chosen for sampling (water depth $2.2 \mathrm{~m}$ ). Sediment characteristics resembled those at the Rassower Strom site

Sampling. Sediment samples from Rassower Strom were taken with a multiple corer (Bamett et al. 1984), modified for application to shallow waters (H. J. Black pers comm.). The corer was operated from the RV 'Prof. Fritz Gessner'. In the shallow Kirr-Bucht (and Klosterloch), samples were taken with a manually 
Table 1. (A) Hydrographical and hydrochemical data (data according to $S$. Dahlke \& H. Baudler pers. comm.) and (B) sediment characteristics of top $10 \mathrm{~cm}$ (data according to $S$. Dahlke pers. comm.) at the sampling locations Kirr-Bucht and Rassower Strom. fw: fresh weight; dw: dry weight

\begin{tabular}{|c|c|c|}
\hline & Kirr-Bucht & $\begin{array}{c}\text { Rassower } \\
\text { Strom }\end{array}$ \\
\hline \multicolumn{3}{|c|}{ (A) Hydrographical and hydrochemical data } \\
\hline Area $\left(\mathrm{km}^{2}\right)$ & 0.15 & 26.7 \\
\hline Volume $\left(\mathrm{m}^{3}\right)$ & 70000 & 4960000 \\
\hline Mean depth $(\mathrm{m})$ & $<0.5$ & 2.5 \\
\hline Max depth (m) & 1.2 & 6.00 \\
\hline Depth of sampling stations (m) & $0.6-0.8$ & $3.2-4.2$ \\
\hline Mean salinity & 5.5 & 9.4 \\
\hline Nitrate (Jan-Apr) $\left(\mu \mathrm{mol} \mathrm{l}^{-1}\right)^{\mathrm{a}}$ & 27.4 & 3.8 \\
\hline Ammonia (Jan-Apr) $\left(\mu \mathrm{mol} \mathrm{l}^{-1}\right)^{\mathrm{o}}$ & 6.3 & 1.2 \\
\hline Phosphate (Jan-Apr) $\left(\mu \mathrm{mol} \mathrm{l} \mathrm{l}^{-1}\right)^{\mathrm{a}}$ & 0.7 & 0.3 \\
\hline Secchi depth (summer) $(\mathrm{m})$ & 0.3 & 2.6 \\
\hline \multicolumn{3}{|l|}{ (B) Sediment characteristics } \\
\hline Sediment type & Sand & Sandy mud \\
\hline Fraction $<63 \mu \mathrm{m}(\%)$ & $5-10$ & $30-90$ \\
\hline Water content $(\% \mathrm{fw})$ & $20-50$ & $15-90$ \\
\hline Organic carbon ( $\%$ dw $)$ & 0.9 & 1.8 \\
\hline Nitrogen $(\% d w)$ & 0.12 & 0.23 \\
\hline Ammonia in pore water $\left(\mu m o l l^{-1}\right)$ & 64.8 & 149.2 \\
\hline Phosphate in pore water $\left(\mu \mathrm{mol} \mathrm{l} l^{-1}\right)$ & 11.0 & 14.2 \\
\hline ¿1996-1998 & & \\
\hline
\end{tabular}

operated coring device. All incubations were carried out in limpid plexiglass tubes (length $300 \mathrm{~mm}$, diameter $100 \mathrm{~mm}$ ) containing undisturbed sediment cores (adjusted to a length of $100 \mathrm{~mm}$ ) and approximately 1.11 of ambient water.

Sediment cores were incubated in 2 different manners: one set was exposed to the natural irradiance regime in situ, while the other set was exposed to controlled irradiances in the laboratory.

In situ incubations. For in situ incubations sediment cores were taken in the morning, prepared for incubation and allowed to equilibrate for a period of $1.5 \mathrm{~h}$ in situ before measurements were started. Three incubation tubes were tightly wrapped in aluminium foil for complete exclusion of irradiance, and another 3 sediment cores were taken for incubation at ambient irradiance conditions. All plexiglas tubes were put into a lowering frame and deposited on the sea bottom. Prior to taking water samples, the water column in the tubes was stirred by a built-in, manually operated stirrer to dissolve vertical gradients in oxygen concentration. Primary production rates were derived from changes of oxygen concentrations in the incubation tubes, as determined by Winkler titration (triplicate set of samples from each sediment core) according to Grasshoff et al. (1983). The endpoint of titration was determined potentiometrically (Mettler DL 21 Titrator). The standard error of the mean of triplicates was about $2 \%$ of the mean. In most cases a forenoon incubation phase was differentiated from an afternoon phase. Forenoon incubations typically lasted from 10:00 to 14:00 h and afternoon incubations from 14:00 to 18:00 h. In January in situ incubations were carried out from 11:00 to 16:00 h. During in situ incubations, photosynthetically active radiation (PAR) in the water was continuously recorded by a Li-Cor underwater sensor (LI-193SA). For calculation of the vertical attenuation coefficient $(k)$, underwater irradiance was determined in 0.1 and $0.5 \mathrm{~m}$ depth intervals for Kirr-Bucht and Rassower Strom, respectively ( 8 to 10 measuring points). The function $E_{(z)}=E_{(0)} \exp (-k z)$ was fitted to the irradiance data with $z$ (= depth) and $E_{(z)}$ (= irradiance at depth) as variables and $k$ and $E_{(0)}$ (= underwater surface irradiance) as parameters to be optimized (nonlinear curvefitting procedure of the program 'Fig. $\mathrm{P}^{\otimes}$ for Windows ${ }^{T M \prime}$ ). Atmospheric PAR was also continuously recorded during in situ incubations by a Li-Cor sensor (LI-190SA) in the direct vicinity of the incubation area. Salinity (practical salinity units) and temperature were measured with a conductivity meter (WTW LF 196 with TetraCon 96).

Laboratory incubations. Sediment cores for laboratory incubations ( 6 to 12 replicates) were prepared in a similar manner as described for the in situ incubations. but were allowed to equilibrate overnight. Changes in oxygen concentration were determined by membranecovered polarographic oxygen sensors (WTW TriOxmatic 201) connected to a multichannel oxygen meter (WTW InterLog OXI). All electrodes were arranged in such a way that shading of the sediment surface was avoided. As the light source, a solar simulator (Saalmann $1200 \mathrm{~W}$ ) which allows an area of about $0.5 \mathrm{~m}^{2}$ to be illuminated with photon flux densities of up to $800 \mu \mathrm{mol} \mathrm{m}^{-2} \mathrm{~s}^{-1}$ was used. Photon flux density was adjusted by altering the distance between samples and light source and/or by interposing diffusers, consisting of meshes of refined steel $(630 \mu \mathrm{m})$. The sediment cores were exposed to different irradiances in the range of 20 to $800 \mu \mathrm{mol} \mathrm{m}^{-2} \mathrm{~s}^{-1}$ (see Fig. 3) to obtain information about the characteristics of irradiance dependency of primary production (P-E curve). A long incubation (up to $12 \mathrm{~h}$ ) was chosen at low irradiances in order to achieve good resolution of oxygen fluxes, whereas, at high irradiance levels with enhanced oxygen fluxes, short incubations (minimum of $4 \mathrm{~h}$ ) were sufficient. Dark incubations followed light incubations to obtain information about oxygen consumption of the sediments. Experimental PAR levels were chosen in accordance with their significance for benthic light conditions at the sampling sites. For a period of 1 mo prior to laboratory incubations, minimal, maximal and mean photon flux densities during daily periods of $8 \mathrm{~h}$ ( $4 \mathrm{~h}$ before and $4 \mathrm{~h}$ after midday) were ascertained from continuous atmospheric PAR measurements at 
Table 2. Salinity, temperature, vertical attenuation and concentration of chlorophyll $a$ in the water during sampling

\begin{tabular}{|c|c|c|c|c|c|}
\hline Sampling date & $\begin{array}{l}\text { Salinity } \\
\text { (psu) }\end{array}$ & $\begin{array}{l}\text { Temperature } \\
\left({ }^{\circ} \mathrm{C}\right)\end{array}$ & $\begin{array}{l}\text { Chlorophyll } a \\
\left(\mu \mathrm{g} \mathrm{dm^{-3 } )}\right.\end{array}$ & $\begin{array}{c}\text { Attenuation } \\
\text { coefficient }\left(\mathrm{m}^{-1}\right)\end{array}$ & Remarks \\
\hline \multicolumn{6}{|l|}{ Kírr-Bucht } \\
\hline 1 Jul 1996 & 5.0 & 14.1 & 32.9 & 3.48 & \\
\hline 7 Oct 1996 & 5.6 & 12.9 & 29.6 & 3.37 & \\
\hline 27 Jan 1997 & 6.4 & 1.2 & 12.1 & 1.87 & Ice coverage \\
\hline 7 Apr 1997 & 6.6 & 5.9 & 13.3 & 3.73 & \\
\hline \multicolumn{6}{|l|}{ Rassower Strom } \\
\hline 8 Jul 1996 & 8.2 & 16.9 & 4.5 & 0.66 & \\
\hline 30 Sep 1996 & 8.2 & 12.2 & 4.2 & 0.79 & \\
\hline $15 \mathrm{Jan} 1997^{\mathrm{a}}$ & 9.1 & -0.3 & 2.0 & 0.66 & Ice coverage \\
\hline 14 Apr 1997 & 9.4 & 5.8 & 1.3 & 0.61 & \\
\hline
\end{tabular}

the Institut für Ökologie, Hiddensee, Germany. Taking into account water depth and attenuation, corresponding PAR levels were calculated for the sediment surface at each sampling station. Higher PAR levels were also applied during laboratory incubations to reach light saturation of photosynthesis. All incubations were carried out at in situ temperature in a water bath.

Table 3. Concentration of chlorophyll a in the upper $5 \mathrm{~mm}$ of sediment cores. (A) In situ incubations and (B) laboratory incubations. Data are means \pm SD ( $n=$ no. of samples)

\begin{tabular}{|c|c|c|}
\hline & $\begin{array}{l}\text { Chlorophyll a } \\
\left(\mu \mathrm{cm}^{-1}\right)\end{array}$ & $\mathrm{n}$ \\
\hline \multicolumn{3}{|l|}{ (A) In situ } \\
\hline \multicolumn{3}{|l|}{ Kirr-Bucht } \\
\hline 30 Jun 1996 & $40.32 \pm 2.20$ & 6 \\
\hline 6 Oct 1996 & $35.29 \pm 3.33$ & 6 \\
\hline 27 Jan 1997 & $35.13 \pm 6.96$ & 6 \\
\hline 6 Apr 1997 & $42.84 \pm 2.36$ & 6 \\
\hline \multicolumn{3}{|c|}{ Rassower Strom } \\
\hline 7 May 1996 & $13.51 \pm 1.18$ & 5 \\
\hline 7 Jul 1996 & $20.85 \pm 5.25$ & 6 \\
\hline 28 Sep 1996 & $17.92 \pm 1.92$ & 6 \\
\hline 17 Jan $1997^{\circ}$ & $13.75 \pm 1.93$ & 6 \\
\hline 13 Apr 1997 & $14.82 \pm 1.43$ & 6 \\
\hline \multicolumn{3}{|l|}{ (B) Laboratory } \\
\hline \multicolumn{3}{|l|}{ Kirr-Bucht } \\
\hline 1 Jul 1996 & $40.58 \pm 3.75$ & 6 \\
\hline 7 Oct 1996 & $23.06 \pm 8.59$ & 12 \\
\hline $27 \operatorname{Jan} 1997$ & $34.40 \pm 7.95$ & 6 \\
\hline 7 Apr 1997 & $42.12 \pm 10.33$ & 12 \\
\hline \multicolumn{3}{|c|}{ Rassower Strom } \\
\hline 8 Jul 1996 & $14.01 \pm 3.26$ & 4 \\
\hline 30 Sep 1996 & $15.08 \pm 3.92$ & 10 \\
\hline $15 \operatorname{Jan} 1997^{\circ}$ & $12.59 \pm 1.13$ & 6 \\
\hline 14 Apr 1997 & $13.27 \pm 0.79$ & 12 \\
\hline
\end{tabular}

Determination of chlorophyll a concentrations. At the end of incubations, the top $5 \mathrm{~mm}$ of sediment cores was removed and thoroughly mixed; 5 subsamples of $0.5 \mathrm{~cm}^{3}$ were taken from the slurry with a cut-off syringe and stored deep frozen in polyethylene centrifuge tubes. Analyses were done in accordance with the guidelines of Helsinki Commission (1988), including extraction with $96 \%$ ethanol, followed by spectrophotometric reading at $665 \mathrm{~nm}$ (Perkin Elmer UV/ VIS Spectrometer Lambda 2).

Calculations of benthic primary production. Net benthic production and respiration rates were derived from changes in dissolved oxygen concentrations over time in illuminated and darkened incubation tubes, respectively. Both measurements reflect the oxygen turnover of the entire system, including photoautotrophic and heterotrophic activities. Therefore respiration expresses community respiration, and the term 'net production' (NP) is used instead of 'net primary production'. NP had negative values if oxygen consumption exceeded oxygen production by photosynthesis. Gross production (GP) of sediment cores was calculated as sum. of respiration and NP. GP may be a more appropriate measure of microalgal photosynthesis than NP, because oxygen release in the experimental system - in contrast to oxygen consumption-can only be ascribed to photoautotrophic organisms. Oxygen production rates were converted to carbon fixation rates using a photosynthetic quotient of 1.2 (Mills \& Wilkinson 1986, Oviatt et al. 1986). This quotient was also used to convert oxygen data from literature to carbon values.

The relationship between photosynthesis and irradiance is described by the equation of Webb et al. (1974), as rewritten by Jassby \& Platt (1976):

$$
P=P_{\mathrm{m}}\left[1-\exp \left(-\alpha E / P_{\mathrm{m}}\right)\right]
$$

Production $(P)$ is dependent on irradiance $(E)$ and 2 physiologically interpreted parameters $\left(\alpha\right.$ and $\left.P_{\mathrm{m}}\right)$. The 
parameter $\alpha$ characterizes the slope of the light-saturation curve at low irradiance levels, when photosynthesis is assumed to be proportional to photon flux density. $P_{\mathrm{m}}$ is the maximum photosynthetic rate at optimal illumination, also called photosynthetic capacity. The influence of factors such as temperature, nutrients, or adaptation are represented mathematically by their effect on the parameters $\alpha$ and $P_{\mathrm{m}}$ (Jassby $\&$ Platt 1976). Platt et al. (1980) give an extended form of the equation, including an additional parameter $(\beta)$, to characterize photoinhibition. As the present data showed no indication of photoinhibition, there was no need to apply the latter equation. According to Baumert (1996), an exponential equation is better suited to describe the relationship between photosynthesis and irradiance than a Michaelis-Menten-type formulation. A simultaneous fit of $\alpha$ and $P_{\mathrm{m}}$ to the present data was obtained by using the nonlinear curve-fitting procedure of the program 'Fig. $P^{\otimes}$ for Windows ${ }^{\text {TM }}$ '.

\section{RESULTS}

Salinity, temperature, and concentrations of chlorophyll a

Measurements of benthic primary production in shallow Bodden were performed during 4 campaigns, representing different seasons. Sampling dates, conditions of salinity, temperature, and concentrations of chlorophyll $a$ in the overlying water are listed in Table 2. Temperature ranged from 0 to $17^{\circ} \mathrm{C}$, with no significant difference between the sampling sites. The location KirrBucht is clearly distinguishable from Rassower Strom by lower salinity values and higher chlorophyll a concentrations in the water column.

Chlorophyll a concentrations in the upper $5 \mathrm{~mm}$ of sediment cores are presented in Table 3. Generally there were no significant differences within sets of sediment cores from Kirr-Bucht and Rassower Strom (Tukey test, $5 \%$ level). Sediment chlorophyll a concentrations in KirrBucht samples were about 2.5 times higher compared to Rassower Strom samples. Chlorophyll a showed small variations except for sediment samples taken for laboratory incubations in October 1996 which had significantly lower concentrations (Table 3 ).
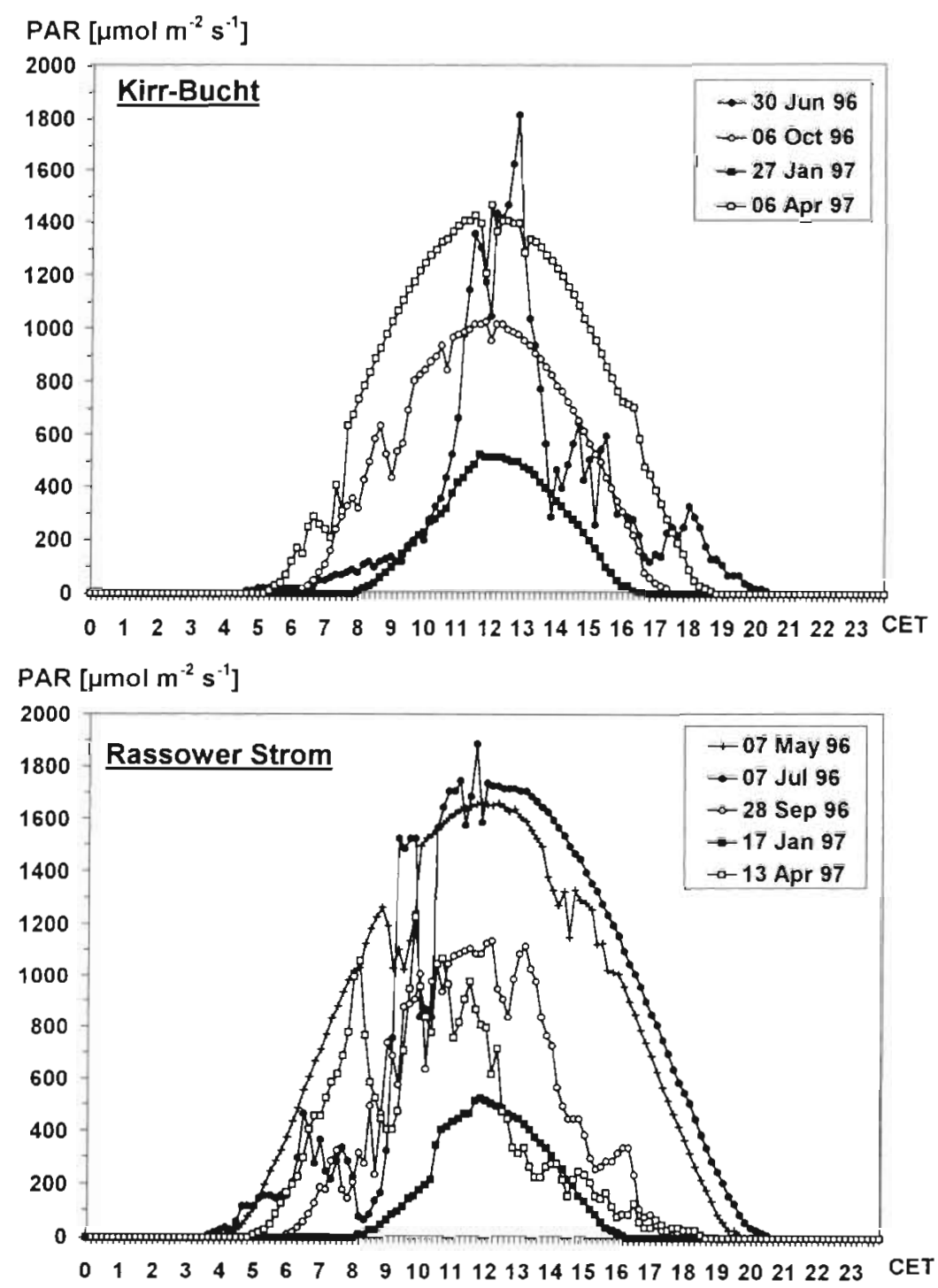

Fig. 2. Course of atmospheric photosynthetically active radiation (PAR) at the sampling stations during in situ incubations. CET: Central European Time

\section{Photosynthetically active radiation (PAR) and attenuation}

PAR conditions during our campaigns are illustrated in Fig. 2. Different irradiances were prevailing during individual days, due to seasons and differences in cloud coverage. An almost ideally Gaussian-shaped PAR distribution curve occurred during in situ incubations at Kirr-Bucht in autumn, winter, and spring, but during the summer campaign the sky was heavily clouded. Strongly fluctuating light conditions were predominant during in situ incubations at Rassower Strom. Altogether, integrated radiation at the water surface ranged from 7.6 to $49.2 \mathrm{~mol}$ photons $\mathrm{m}^{-2} \mathrm{~d}^{-1}$, with a maximal hourly mean of photon flux density of $1727 \mu \mathrm{mol} \mathrm{m} \mathrm{m}^{-2} \mathrm{~s}^{-1}$. 

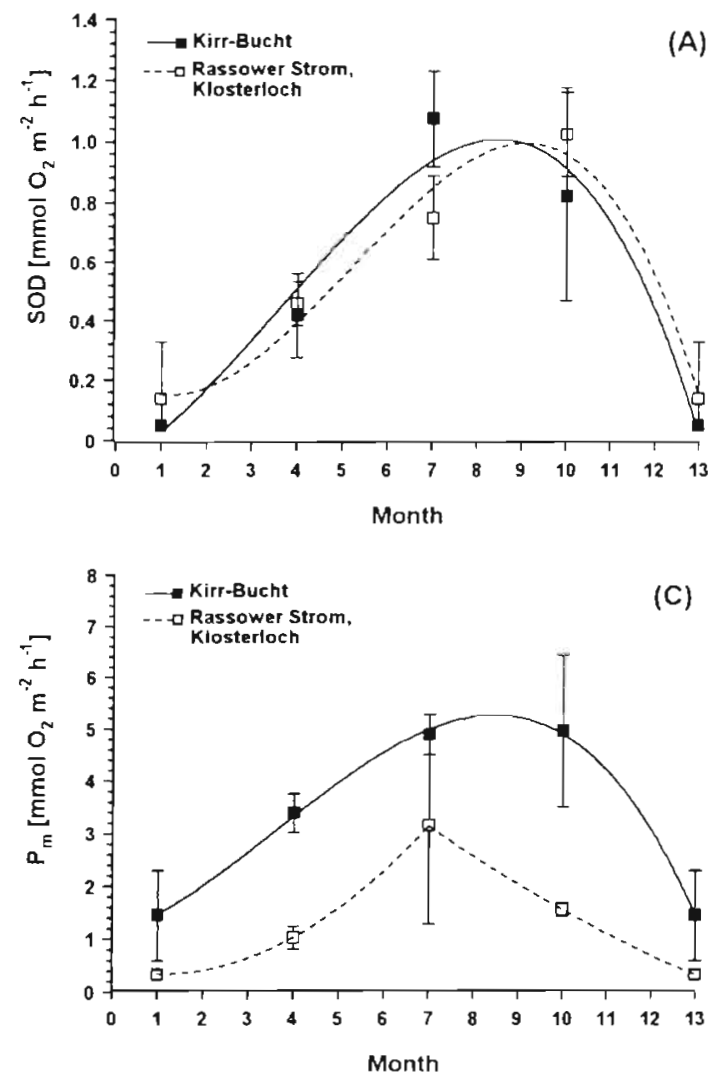

Available PAR at the sediment surface was calculated from data of continuous atmospheric PAR measurements (10 min resolution) and PAR attenuation in water. There was a significant difference in vertical attenuation coefficients between the water body of Kirr-Bucht $\left(2.97 \pm 0.86 \mathrm{~m}^{-1}\right)$ and Rassower Strom $\left(0.66 \pm 0.18 \mathrm{~m}^{-1}\right)$ without a distinct seasonal trend.

\section{Sediment oxygen demand (SOD)}

Oxygen consumption of incubated sediment samples, including respiration of autotrophic and hetero-

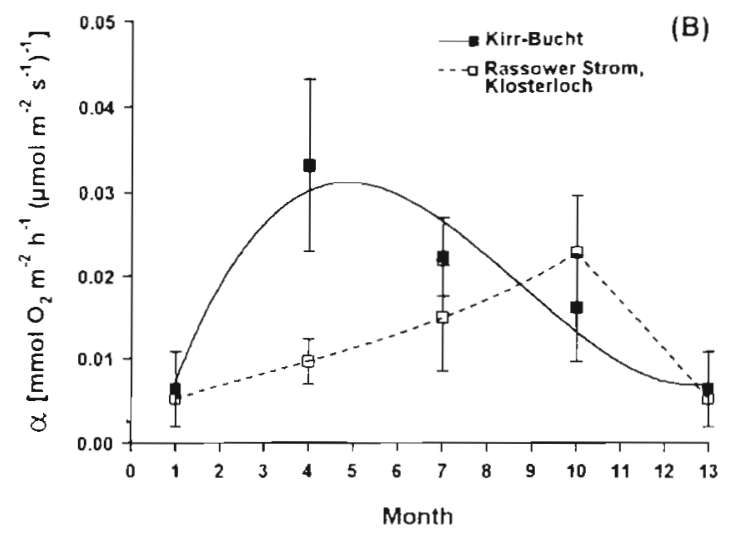

Fig. 3. (A) Sediment oxygen demand (SOD), (B) $\alpha$-values, and (C) $P_{\mathrm{m}}$-values determined by laboratory incubations (means \pm SD) and interpolations obtained by polynomial least-squarefitting; values for January are represented twice to show the seasonal course

trophic organisms as well as chemical oxygen demand, showed marked seasonal differences with the highest rates occurring in summer and autumn (Fig. 3). Absolute values and the seasonal course of SOD did not differ between the 2 sampling sites. The annual range of SOD extended from 0.05 to $1.1 \mathrm{mmol}$ $\mathrm{O}_{2} \mathrm{~m}^{-2} \mathrm{~h}^{-1}$.

\section{Laboratory incubations}

Photon flux densities used in laboratory incubations and corresponding gross production rates are shown

Table 4. Gross production rates (GP) (mg C m $\left.\mathrm{C}^{-2} \mathrm{~h}^{-1}\right)$ as determined by in situ incubations, and corresponding PAR values ( $\mu$ mol $\mathrm{m}^{-2} \mathrm{~s}^{-1}$ ). (A) Forenoon incubation [if no value is given in (B), the incubation period was forenoon + afternoon] and (B) afternoon incubation; data are means $\pm \mathrm{SD}$

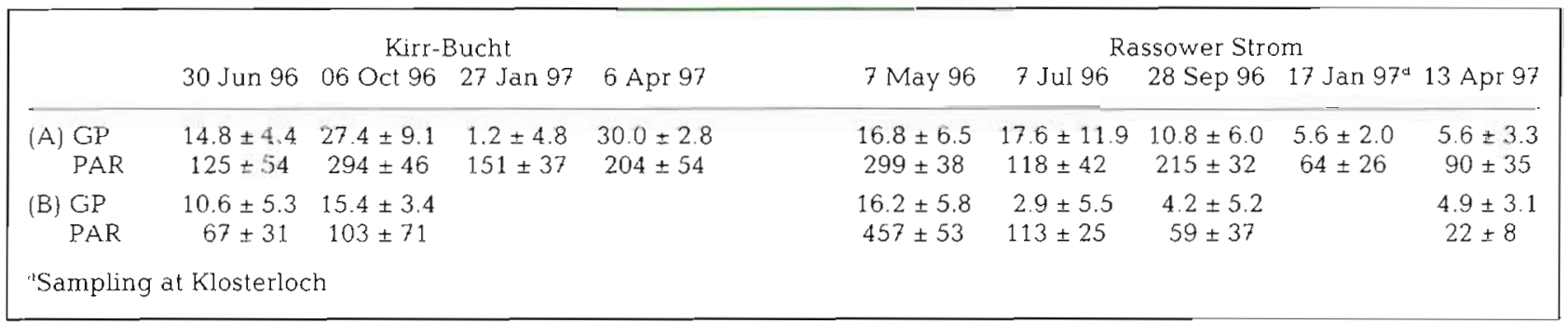


in Fig. 4, which gives examples of P-E curves fitted to the experimental data of individual sediment cores. Examples were chosen from both sampling sites and different seasons. The parameters $\alpha$ and $P_{\mathrm{m}}$ of the P-E curves, which were obtained by a simultaneous fitting procedure, are compiled in Fig. 3. In samples from Kirr-Bucht, $\alpha$ had a minimum in winter, and a maximum in April. In samples from Rassower Strom, $\alpha$ was also lowest in January, but increased until October. The seasonal variation of $P_{\mathrm{m}}$-values was characterized by an increase from a winter minimum to a plateau in summer/autumn for Kirr-Bucht samples, and by a distinct summer maximum for Rassower Strom samples. Standard deviations of $\alpha$ and $P_{\mathrm{m}}$ were quite high in several cases (average: $36 \%$ of the mean), indicating a great variability between individual sediment cores. $P_{\mathrm{m}}$ showed the most obvious, statistically significant, differences between the 2 locations: light-saturated benthic photosynthesis of Kirr-Bucht samples was higher than of Rassower Strom samples ( $p \leq 0.01$, except summer 1998: $p=0.052$; $t$-test).

\section{In situ incubations}

GP rates determined by in situ incubations are summarized in Table 4. Under comparable conditions of irradiance, GP rates tended to be generally higher for KirrBucht than for Rassower Strom samples. Highest GP rates were 30.0 and $17.6 \mathrm{mg} \mathrm{C}$ $\mathrm{m}^{-2} \mathrm{~h}^{-1}$ for Kirr-Bucht and Rassower Strom sediments, respectively. An onset of light saturation may be inferred from data obtained from Rassower Strom on 7 May 1996, when the mean underwater PAR level increased from $300 \mu \mathrm{mol} \mathrm{m} \mathrm{m}^{-2} \mathrm{~s}^{-1}$ in the forenoon to more than $450 \mu \mathrm{mol} \mathrm{m} \mathrm{m}^{-2} \mathrm{~s}^{-1}$ in the afternoon, without any corresponding increase in GP rates. In the afternoon of 7 July 1996, a GP rate of only $2.9 \mathrm{mg} \mathrm{C} \mathrm{m}^{-2} \mathrm{~h}^{-1}$ was measured, which is very low compared to $17.6 \mathrm{mg} \mathrm{C} \mathrm{m} \mathrm{m}^{-2} \mathrm{~h}^{-1}$ determined in the forenoon for the same PAR level. The low value is doubtful and obviously caused by coverage of the incubation tube by sedimented aggregates. This value was not used in further calculations. Lowest and highest in situ GP rates differed by a factor of 4.2 and 25 at Rassower Strom and Kirr-Bucht, respectively.
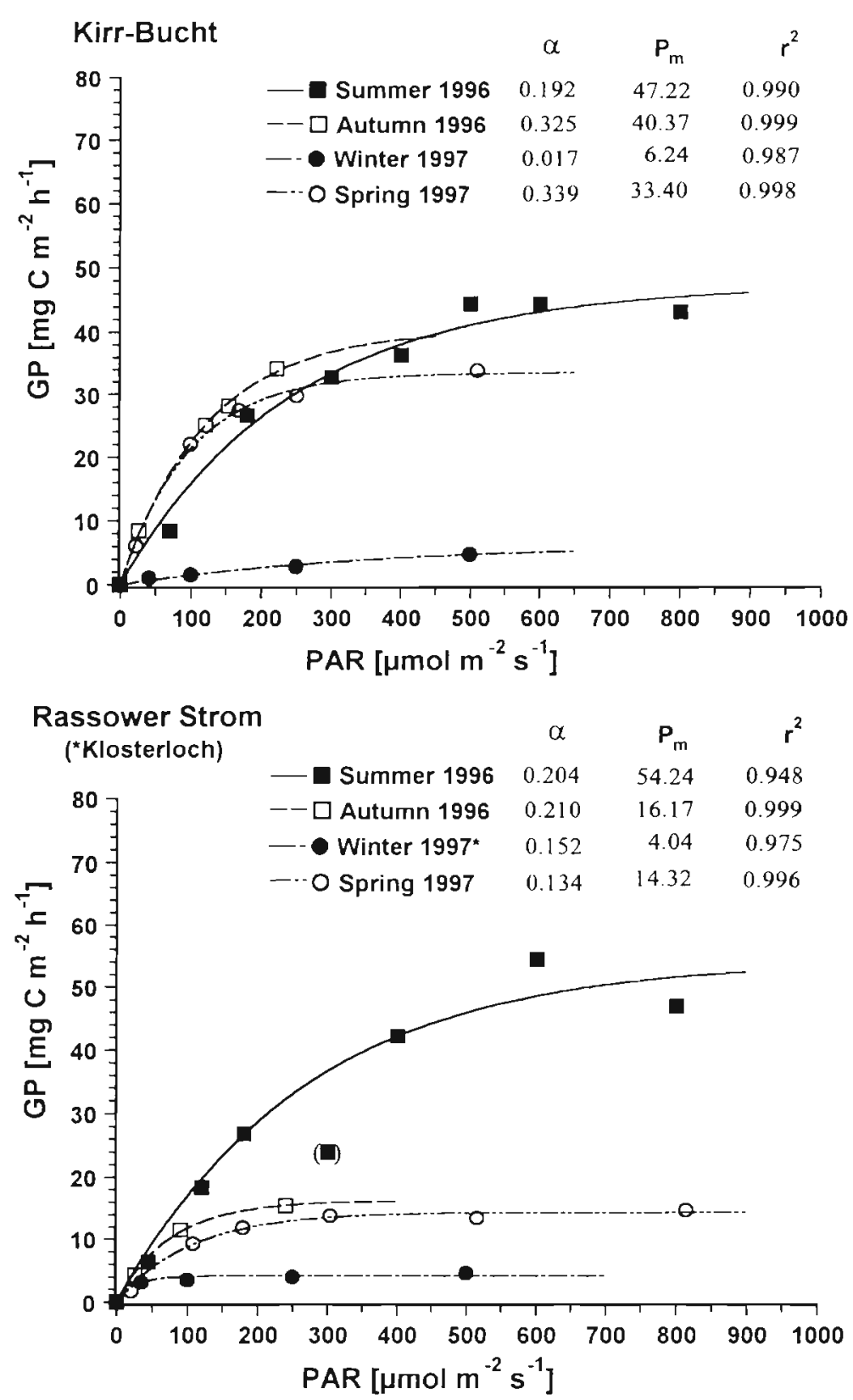

Fig. 4. Gross production rates (GP) of individual sediment cores versus irradiance. $\alpha$ : $\mathrm{mg} \mathrm{C} \mathrm{m} \mathrm{C}^{-2} \mathrm{~h}^{-1}\left(\mu \mathrm{mol} \mathrm{m} \mathrm{m}^{-2} \mathrm{~s}^{-1}\right)^{-1} ; P_{\mathrm{m}}: \mathrm{mg} \mathrm{C} \mathrm{m} \mathrm{m}^{-2} \mathrm{~h}^{-1} ; \mathrm{r}^{2}$ : dimensionless coefficient of determination; data point in parentheses (Rassower Strom, summer 1996) was obtained under poorly defined light conditions, when work at the incubation system caused shading of the samples

\section{Comparison between in situ and laboratory GP rates}

GP rates derived from laboratory incubations were extrapolated to the specific conditions (varying solar irradiation, water depth, attenuation coefficient) that occurred during the in situ incubations. The parameters shown in Fig. 3 (SOD, $\alpha, P_{m}$ ) were used for these 
Table 5. Gross production rates (GP) (mg C m $\left.\mathrm{Ch}^{-2} \mathrm{~h}^{-1}\right)$ as modeled for irradiance conditions during in situ incubations. For corresponding PAR values see Table 4. Values of the parameters of the photosynthesis model were derived from data of the laboratory incubations. (A) Forenoon incubation [if no value is given in (B), the incubation period was forenoon + afternoon] and (B) afternoon incubation; data are means $\pm \mathrm{SD}$

\begin{tabular}{|c|c|c|c|c|c|c|c|c|c|}
\hline & \multicolumn{4}{|c|}{ Kirr-Bucht } & \multicolumn{5}{|c|}{ Rassower Strom } \\
\hline & 30 Jun 96 & 6 Oct 96 & $27 \operatorname{Jan} 97$ & 6 Apr 97 & 7 May 96 & 7 Jul 96 & 28 Sep 96 & $17 \operatorname{Jan} 97^{\alpha}$ & 13 Apr 97 \\
\hline (A) GP & $20.5 \pm 6.3$ & $30.3 \pm 3.2$ & $6.9 \pm 1.3$ & $28.6 \pm 3.3$ & $13.8 \pm 0.7$ & $13.1 \pm 4.0$ & $14.9 \pm 0.4$ & $2.0 \pm 0.6$ & $5.6 \pm 1.6$ \\
\hline (B) GP & $12.6 \pm 4.8$ & $13.2 \pm 8.3$ & & & $15.1 \pm 0.2$ & $12.9 \pm 2.2$ & $8.2 \pm 3.3$ & & $1.9 \pm 0.6$ \\
\hline
\end{tabular}

calculations. Table 5 shows a compilation of the 'calculated GP rates'. Generally these rates were in the same range as GP rates derived from in situ incubations ('measured GP rates'). Major differences between measured and calculated rates occurred in the case of incubations carried out in January, and in the afternoon of 13 April 1997. These data excluded, the mean difference between measured and calculated GP rates was $\pm 20 \%$. Only 1 of all datasets showed a statistically significant difference between measured and calculated data (dataset from 17 January 1997; Tukey-test, $5 \%$ level). In Fig. 5 the in situ GP rates were plotted versus calculated rates (laboratory rates, extrapolated to in situ conditions), showing an acceptable relationship between the 2 datasets $\left(R^{2}=0.833\right)$.

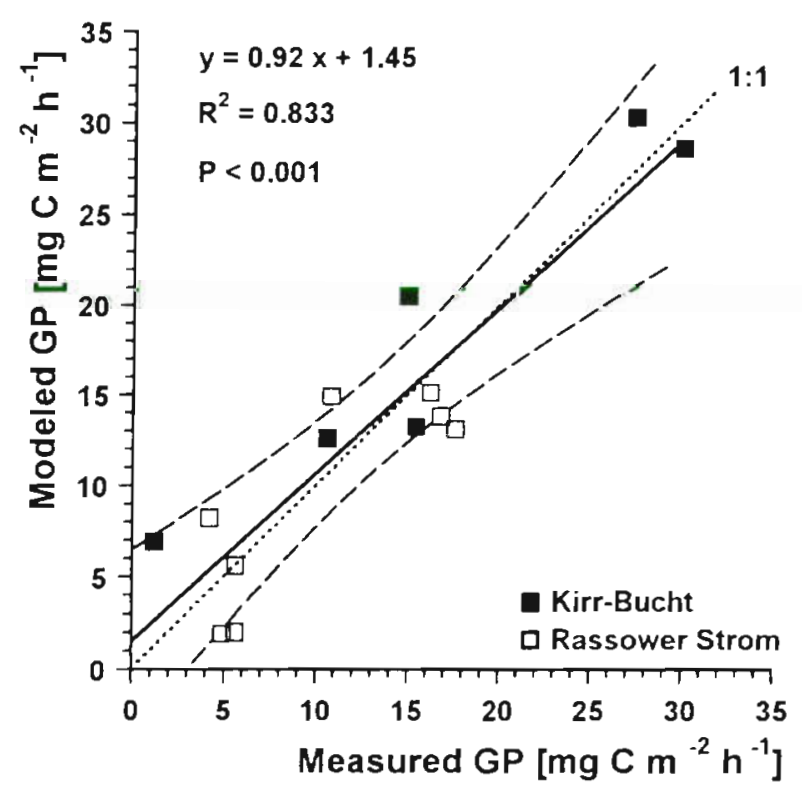

Fig. 5. Regression of GP rates as modeled for irradiance conditions during in situ incubations against GP rates as determined by in situ incubations; confidence interval for the fitted curve is given at the $95 \%$ probability level

\section{Estimation of monthly and annual production rates}

The incubations, which were carried out once per season, provided information about sediment oxygen consumption rates and P-E parameters at that time. A seasonal cycle of benthic primary production was achieved by temporal interpolation (polynomial or linear least-square-fitting procedures; Fig. 3) between experimentally determined parameters.

Monthly rates of primary production of the microphytobenthos were obtained by running the photosynthesis model (Webb et al. 1974, Jassby \& Platt 1976) with solar irradiance data and interpolated parameters of the P-E relationship (Fig. 6). As a consequence of the seasonality of solar irradiance and P-E parameters, a pronounced time course of benthic primary production resulted. Maximal GP rates in summer were about 10 and $4 \mathrm{~g} \mathrm{C} \mathrm{m}^{-2} \mathrm{mo}^{-1}$ for Kirr-Bucht and Rassower Strom, respectively. In winter GP at both sites decreased to values below $0.5 \mathrm{~g} \mathrm{C} \mathrm{m}^{-2} \mathrm{mo}^{-1}$. NP had positive values around $4 \mathrm{~g} \mathrm{C} \mathrm{m}^{-2} \mathrm{mo}^{-1}$ in summer, and negative values of around $4 \mathrm{~g} \mathrm{C} \mathrm{m}^{-2} \mathrm{mo}^{-1}$ in late autumn at Kirr-Bucht. At Rassower Strom, according to the model, no positive NP of the microphytobenthos should be possible during the entire year. The annual carbon budget (July 1996 to June 1997) amounted to 60.5 (GP) and $5.1 \mathrm{~g} \mathrm{C} \mathrm{m}^{-2}$ (NP) for the sediments sampled at Kirr-Bucht, and to 23.4 (GP) and $-30.6 \mathrm{~g} \mathrm{C} \mathrm{m}^{-2}$ (NP) for the sediments of Rassower Strom. The values reported refer to the specific water depth the samples were taken from (Kirr-Bucht: $0.6 \mathrm{~m}$; Rassower Strom: $3.4 \mathrm{~m})$.

A serious difference in conditions of benthic primary production at both sampling sites due to different optical properties of the overlying water became obvious when irradiances at the sediment surface beneath different water depths were taken for calculations of benthic primary production (Fig. 6). Beneath phytoplankton-rich, turbid waters, such as those predominating at eutrophicated Kirr-Bucht, a shortage of irradiance at $3.4 \mathrm{~m}$ depth would allow no primary production at all. Negative values of NP simply reflect 

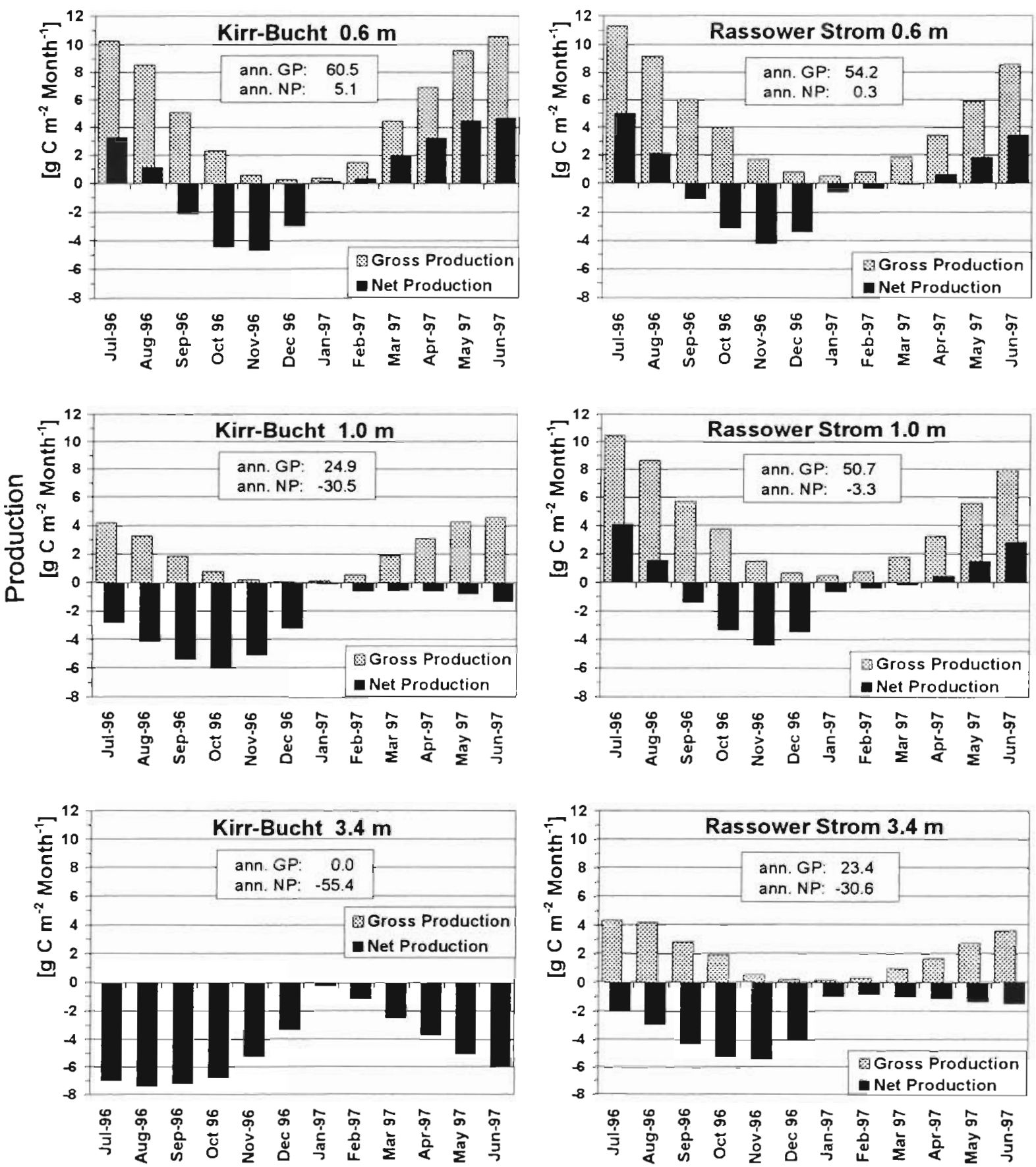

Fig. 6. Estimated variation in primary production of benthic microalgae, modeled for light conditions in different water depths for Kirr-Bucht and Rassower Strom sediments. Sampling depth in Kirr-Bucht and Rassower Strom was 0.6 and $3.4 \mathrm{~m}$, respectively Annual rates of GP and NP (net production) are given as $\mathrm{g} \mathrm{C} \mathrm{m}^{-2} \mathrm{yr}^{-1}$

the respiration of the benthic community and indicate that the respired organic carbon could not be delivered by authochthonous production of benthic microalgae. In contrast to this, the less eutrophicated and less turbid water at Rassower Strom resulted in a photon flux density at $3.4 \mathrm{~m}$ depth that allowed significant GP. Estimations of benthic primary production at an intermediate water depth of $1 \mathrm{~m}$ (Fig. 6) resulted in higher areal production rates at Rassower Strom as compared to Kirr-Bucht, where at that depth no positive NP would be possible at any time during the year. The annual carbon budget (July 1996 to June 1997) at a depth of $1 \mathrm{~m}$ would be $25 \mathrm{~g} \mathrm{C} \mathrm{m}^{-2} \mathrm{GP}$ and $-30 \mathrm{~g} \mathrm{C}$ $\mathrm{m}^{-2} \mathrm{NP}$ for sediments sampled at Kirr-Bucht and $51 \mathrm{~g}$ 
$\mathrm{Cm}^{-2} \mathrm{GP}$ and $-3 \mathrm{~g} \mathrm{C} \mathrm{m}^{-2} \mathrm{NP}$ for sediments at Rassower Strom.

\section{DISCUSSION}

Production rates obtained from in situ incubations depended to a great extent on the irradiance conditions that prevailed during sampling. Nevertheless, in situ production rates are a true reflection of benthic primary production by microalgae for the period sampled. The values can also be used to validate calculations based on the photosynthesis model. Hourly rates of benthic primary production (Table 4) ranged from 1.2 to $30 \mathrm{mg} \mathrm{C} \mathrm{m}^{-2} \mathrm{~h}^{-1}$, thus varying by a factor of 25 . These rates were significantly lower than values reported for intertidal flats during low tide, when the sediments were directly exposed to light (Colijn \& de Jonge 1984, Gätje 1992). Wasmund (1986), who measured primary production of microphytobenthos at Kirr-Bucht between 1978 and 1981, found a range of GP rates from 7 to $130 \mathrm{mg} \mathrm{C} \mathrm{m}^{-2} \mathrm{~h}^{-1}$ in the period March to October. The findings of Wasmund (1986) relate to a water depth of only 15 to $20 \mathrm{~cm}$, compared to $60 \mathrm{~cm}$ in our investigation. Differences in water depth have a distinct effect on light availability, due to the high turbidity of water at Kirr-Bucht. Daily rates of benthic primary production reported by Nienhuis \& de Bree (1984) for the brackish Lake Grevelingen, The Netherlands (water depth 1 to $2 \mathrm{~m}$ ), ranged from about 0 to $500 \mathrm{mg} \mathrm{C} \mathrm{m}^{-2} \mathrm{~d}^{-1}$, which is quite similar to our values ( 7.6 to $319 \mathrm{mg} \mathrm{C} \mathrm{m}^{-2} \mathrm{~d}^{-1}$ ).

More generalized statements about benthic primary production can be obtained by modeling production, taking into account its dependency on irradiance. For phytoplankton it has been shown that it is feasible to estimate in situ primary production from parameters of P-E curves, obtained in laboratory incubators (Tilzer et al. 1993), and this approach is commonly recommended for investigations on phytoplankton productivity (e.g. Prézelin et al. 1991, Sakshaug et al. 1997). Our investigations are the first to describe P-E relationships for intact sediment cores from Bodden waters and therefore are an approach to modeling microphytobenthic production in these waters. The data showed a reasonably good agreement between measured and modeled GP rates $\left(R^{2}=0.83\right)$, supporting the applicability of P-E relationships for calculation of benthic primary production. Differences between measured and modeled GP rates may arise from several sources. These may include errors in determining oxygen exchange rates, precisely calculating available PAR at sediment surface, or stimulation of oxygen-related processes during handling of the sediment cores. The main reason, however, is the heterogeneity of incubated sediments. Each sediment core has to be regarded as an individual system of high complexity, composed of different associations of oxygen consumers and oxygen producers. Bearing this in mind, the differences between measured and modeled GP rates (Fig. 5) can be looked upon as relatively small.

The time-consuming investigations had to be concentrated on a limited number of campaigns; however, the objective to show seasonal differences in sediment oxygen demand (SOD) and photosynthetic activity of benthic microalgae was met since a clear seasonal trend became obvious. While the concentrations of chlorophyll $a$ in the upper $5 \mathrm{~mm}$ of the sediment were rather uniform throughout the year (Table 3), SOD, $\alpha$, and $P_{\mathrm{m}}$ showed a strong seasonality (Fig. 3). SOD was up to 20 times higher in summer than in winter. This should be due to higher heterotrophic activities at high temperatures and to higher inputs to the upper sediment layer of easily degradable organic material originating from benthic and planktonic primary production. The low SOD in winter is probably attributed to the fact that the winter 1996/1997 was extraordinarily cold. Maximum values of $\alpha$ occurred at different times in Kirr-Bucht (spring) and Rassower Strom (autumn). This parameter is supposed to be independent of temperature but dependent on adaptation to irradiance (Straškraba \& Gnauck 1983, Kirk 1994, Epping 1996). It remains an open question whether the local history of underwater irradiance conditions at the sampling sites prior to sampling could explain the seasonal pattern of $\alpha$ by different adaptation to light. The time pattern of $P_{m}$ however, followed the annual increase and decrease of irradiance and water temperature.

Temporal interpolation of the parameters as visualized in Fig. 3 allowed an estimation of the seasonal course of benthic primary production, which is needed for a calculation of the $\mathrm{C}$ budget on a longer time scale. An indication of the predictive power of the interpolated parameters may be derived from Fig. 7. GP rates measured in situ in May 1996 were somewhat above the P-E curve, calculated on basis of $\alpha$ - and $P_{\mathrm{m}}$-values, which were determined in April 1997. On the contrary, the in situ data from May were very close to a P-E curve, created with values for $\alpha$ and $P_{m}$ which were interpolated for May according to Fig. 3.

Calculated annual rates of benthic gross primary production ranged from 23 to $60 \mathrm{gC} \mathrm{m}^{-2} \mathrm{yr}^{-1}$ at Rassower Strom $(3.4 \mathrm{~m})$ and Kirr-Bucht $(0.6 \mathrm{~m})$, respectively. They are well within the range of microphytobenthic primary production reported by numerous authors for a great variety of habitats (Rizzo et al. 1992, Schreiber \& Pennock 1995). Wasmund (1986) reported a microphytobenthic GP for a station at Kirr-Bucht 
(about $0.2 \mathrm{~m}$ depth) of 60 to $93 \mathrm{~g} \mathrm{C} \mathrm{m}^{-2}$ in the period April to October. For our station at Kirr-Bucht (0.6 $\mathrm{m}$ depth), GP during this period amounted to $53 \mathrm{~g} \mathrm{C} \mathrm{m}^{-2}$. Benthic GP for a water depth of $0.2 \mathrm{~m}$ would be $92 \mathrm{~g} \mathrm{C}$ $\mathrm{m}^{-2}$ for the period April to October. Although the agreement with the data of Wasmund (1986) is reasonable, it should be treated with some caution. Whether our modeled data can be extended to such shallow water is doubtful, because physical conditions in a water depth of $0.2 \mathrm{~m}$ are supposedly quite different from the ones in a water depth of $0.6 \mathrm{~m}$, where our samples were taken, due to stronger wave action and episodical exposure to the atmosphere.

At the particular sampling spots in KirrBucht and Rassower Strom, conditions for benthic primary production with respect to irradiance were quite similar, despite the fact that the water was about 6 times deeper at the Rassower Strom spot. This is due to the specific coincidences of water transparency and water depth at both locations (low attenuation/great depth at Rassower Strom, high attenuation/low depth at KirrBucht). As a long-term average, the sediment surface at Rassower Strom at $3.4 \mathrm{~m}$ water depth still received about $2 / 3$ of the irradiance Kirr-Bucht sediments at $0.6 \mathrm{~m}$ water depth received. If the bathymetry of the whole water basins of Kirr-Bucht and Rassower Strom are taken into account, there should be a much more severe light limitation at the bottom of Kirr-Bucht than of Rassower Strom. The latter location contains rather clear water, and large areas are shallower than the particular spot where our samples were taken. In contrast, high phytoplankton density causes severe attenuation of irradiance in the eutrophicated Kirr-Bucht, where our sampling station was located more or less at mean water depth.

Knowledge of the P-E relationship allowed us to model GP and NP (net production) rates of benthic microalgae under irradiance conditions prevailing at different water depths (Fig. 6). The deeper the water is, the more pronounced the differences in benthic microalgal production between the eutrophic KirrBucht and the mesotrophic Rassower Strom are; while there are only minor differences between both locations at a water depth of $0.6 \mathrm{~m}$, there is a completely different pattern of production at a depth of $3.4 \mathrm{~m}$. The seasonal patterns of benthic GP and NP rates modeled for Rassower Strom are almost identical at water depths of 0.6 and $1.0 \mathrm{~m}$ and even resemble the pattern of production at Kirr-Bucht at $0.6 \mathrm{~m}$ depth, despite the fact that at the latter location much less irradiance should be available at the sediment sur- face. This indicates that the higher availability of irradiance, given for Rassower Strom samples, could not be utilized due to an onset of light saturation of photosynthesis. But at a water depth where availability of irradiance still allowed significant benthic primary production at Rassower Strom, no further production at Kirr-Bucht would be possible (Fig. 6: $3.4 \mathrm{~m}$ ). These findings support the hypothesis, formulated in the introduction, that a high level of eutrophication reduces the quantity of benthic microalgal primary production. The main reason for a reduced benthic production of microalgae at Kirr-Bucht is the high eutrophication of the water. This favours pelagic over benthic production, since dense phytoplankton causes a significant shading of the sediment surface. The disappearance of extended stands of submersed macrophytes in Bodden waters during the last decades was a visible sign of a severe deterioration of living conditions for benthic photoautotrophs due to increased turbidity. It can be deduced from our results that for benthic microalgae, which are often neglected in such considerations, conditions also had changed for the worse during recent decades. A reduction of nutrient loads to the Bodden waters will in the long term improve water transparency and enhance primary production of benthic microalgae. A recovery of microphytobenthos on sediments formerly uninhabited will start a self-enhancing process. Photosynthetic activity of microphytobenthos is well known to raise oxygen concentration and penetration depth in surface sediments (Revsbech et al. 1981, Maclntyre et al. 1996, Berninger \& Huettel 1997). The release of nutrients (ammonia and phosphorus) from sediments 
to the water is thereby reduced (Carlton \& Wetzel 1988, Rizzo et al. 1992, Wiltshire 1992), resulting in a reduction of nutrient load to the Bodden from internal sources. Benthic microalgae therefore can exert an important influence on the nutrient balance of the waters and may significantly contribute to their deeutrophication.

Acknowledgements. The authors thank the crew of RV 'Prof. Fritz Gessner' for assistance during sampling as well as $\mathrm{H}$. Klutentreter and I. Kreutzer for their support in the laboratory. We are grateful to Helmut Hübel, Desmond Murphy, and 4 anonymous reviewers for useful comments on the manuscript. This research is part of the joint research project 'Ökosystem Boddengewässer-Organismen und Stoffhaushalt ÖKOBOD' (ecosystem Bodden-organisms and nutrient balance), financed by the German BMBF (Bundesministerium für Bildung, Wissenschaft, Forschung und Technologie).

\section{LITERATURE CITED}

Barnett. PRO, Watson J, Conelly D (1984) A multiple corer for taking virtually undisturbed samples from shelf, bathyal and abyssal sediments. Oceanol Acta 7:399-409

Baumert $H$ (1996) On the theory of photosynthesis and growth in phytoplankton. Part I: Light limitation and constant temperature. Int Rev Ges Hydrobiol 81:109-139

Berninger UG, Huettel $M$ (1997) Impact of flow on oxygen dynamics in photosynthetically active sediments. Aquat Microb Ecol 12:291-302

Cahoon LB, Beretich GR Jr, Thomas CJ, McDonald AM (1993) Benthic microalgal production at Stellwagen Bank, Massachusetts Bay, USA. Mar Ecol Prog Ser 102:179-185

Carlton RG, Wetzel RG (1988) Phosphorus flux from lake sediments: effect of epipelic algal production. Limnol Oceanogr 33:562-570

Colijn F (1982) Light absorption in the waters of the EmsDollard Estuary and its consequences for the growth of phytoplankton and microphytobenthos. Neth J Sea Res 15:196-216

Colijn F, de Jonge VN (1984) Primary production of microphytobenthos in the Ems-Dollard-Estuary. Mar Ecol Prog Ser 14:185-196

Correns $M$ (1976) Charakteristische morphometrische Daten der Bodden- und Haffgewässer der DDR. Vermessungstechnik 24:459-461

Dahlke S (1994) Die Entwicklung der Gewässerbeschaffenheit der Nordrügenschen Boddengewässer seit 1989. Bodden 1:51-68

Epping HG (1996) Benthic phototrophic communities and the sediment-water exchange of oxygen, Mn(II), Fe(II), and silicic acid. PhD thesis, Rijksuniversiteit Groningen

Gätje C (1992) Artenzusammensetzung, Biomasse und Primärproduktion des Mikrophytobenthos des Elbe-Ästuars. PhD thesis, Universität Hamburg

Grasshoff K, Erhardt M, Kremling K (1983) Methods of seawater analysis. Verlag Chemie, Weinheim

Helsinki Commission (1988) Guidelines for the Baltic monitoring programme for the third stage. Baltic Sea Environ Proc 27D:1-60

Hübel H, Wolff C, Meyer-Reil LA (1998) Salinity, inorganic nutrients, and primary production in a shallow coastal inlet in the southern Baltic Sea (Nordrügensche Bodden).
Results from long-term observations (1960-1989), Int Rev Ges Hydrobiol 83:499-519

Jassby AD, Platt I (1976) Mathematical formulation of the relationship between photosynthesis and light for phytoplankton. Limnol Oceanogr 21:540-547

Kirk JTO (1994) Light and photosynthesis in aquatic ecosystems. Cambridge University Press, Cambridge

Köster M, Dahlke S, Meyer-Reil LA (1997) Microbiological studies along a gradient of eutrophication in a shallow coastal inlet in the southern Baltic Sea (Nordrügensche Bodden). Mar Ecol Prog Ser 152:27-39

MacIntyre HL, Geider RJ, Miller DC (1996) Microphytobenthos: the ecological role of the 'Secret Garden' of unvegetated, shallow-water marine habitats. I. Distribution, abundance and primary production. Estuaries 19:186-201

Mills DK, Wilkinson $M$ (1986) Photosynthesis and light in estuarine benthic microalgae. Bot Mar 29:125-129

Nausch G, Schlungbaum G (1991) Eutrophication and restoration measures in the Darss-Zingst Bodden chain. Int Rev Ges Hydrobiol 76:451-463

Nienhuis PH, de Bree BHH (1984) Carbon fixation and chlorophyll in bottom sediment in brackish Lake Grevelingen, The Netherlands. Neth J Sea Res 18:337-359

Oviatt CA, Keller AA, Sampou PA, Beatty LL (1986) Patterns of productivity during eutrophication: a mesocosm experiment. Mar Ecol Prog Ser 28:69-80

Pankow H, Wasmund N (1994) Produktionsbiologie und Soziologie des Makro- und Mikrophytobenthos der DarssZingster Boddenkette. Rostock Meeresbiol Beitr 2:61-68

Platt T, Gallegos CL, Harrison WG (1980) Photoinhibition of photosynthesis in natural assemblages of marine phytoplankton. J Mar Res 38:687-701

Prézelin BB, Tilzer MM, Schofield O, Haese C (1991) The control of the production process of phytoplankton by the physical structure of the aquatic environment with special reference to its optical properties. Aquat Sci 53:136-186

Revsbech NP, Jørgensen BB, Brix O (1981) Primary production of microalgae in sediments measured by oxygen microprofile, $\mathrm{H}^{14} \mathrm{CO}_{3}$-fixation, and oxygen exchange methods. Limnol Oceanogr 26:717-730

Rizzo WM, Lackey GJ, Christian RR (1992) Significance of euphotic, subtidal sediments to oxygen and nutrient cycling in a temperate estuary. Mar Ecol Prog Ser 86: $51-61$

Sakshaug E, Bricaud A, Dandonneau Y, Falkowski PG, Kiefer DA, Legendre L, Morel A, Parslow J, Takahashi M (1997) Parameters of photosynthesis: definitions, theory and interpretation of results. J Plankton Res 19:1637-1670

Schiewer U, Schumann R, Heerkloss R, Klinkenberg G (1994) Hypertrophierung der Darss-Zingster BoddenketteStruktur- und Funktionsveränderungen im Plankton. Rostock Meeresbiol Beitr 2:149-177

Schlungbaum G, Baudler H, Nausch G (1994) Die DarssZingster Boddenkette-ein typisches Flachwasserästuar an der südlichen Ostseeküste. Rostock Meeresbiol Beitr 2 $5-26$

Schreiber RA, Pennock JR (1995) The relative contribution of benthic microalgae to total microalgal production in a shallow sub-tidal estuarine environment. Ophelia 42: $335-3.52$

Sloth NP, Riemann B, Nielsen LP, Blackburn TH (1996) Resilience of pelagic and benthic microbial communities to sediment resuspension in a coastal ecosystem, Knebel Vig, Denmark. Estuar Coast Shelf Sci 42:405-415

Straškraba M, Gnauck A (1983) Aquatische ÖkosystemeModellierung und Simulation. Gustav Fischer Verlag, Stuttgart 
Tilzer MM, Häse C, Conrad I (1993) Estimation of in situ primary production from parameters of the photosynthesislight curve obtained in laboratory incubators. ICES Mar Sci Symp 197:181-195

Wasmund N (1986) Ecology and bioproduction in the microphytobenthos of the chain of shallow inlets (Boddens) south of the Darss-Zingst Peninsula (Southern Baltic Sea). Int Rev Ges Hydrobiol 71:153-178

Editorial responsibility: Otto Kinne (Editor),

Oldendort/Luhe, Germany
Webb WL, Newton M, Starr D (1974) Carbon dioxide exchange of Alnus rubra: a mathematical model. Oecologia 17:281-291

Wiltshire KH (1992) Untersuchungen zum Einfluss des Mikrophytobenthos auf den Nährstoffaustausch zwischen Sediment und Wasser in der Tide-Elbe. GKSS-Forschungszentrum Geesthacht, GKSS 92/E/47:1-174

Submitted: April 21, 1998; Accepted: October 26, 1998 proofs received from author(s): March 9, 1999 